\title{
TEMPERATURE LEVELS IN HOT-AIR OVENS
}

\author{
BY \\ E. M. DARMADY AND R. BARRINGTON BROCK \\ From the Portsmouth and Isle of Wight Area Pathological Service
}

(RECEIVED FOR PUBLICATION OCTOBER 14, 1954)

During the past few years the popularity of hotair ovens for sterilizing has been increasing. This is partly due to the ease with which they sterilize small objects such as syringes, and partly because they are inexpensive to run. At the same time autoclaves, which appear to be popular in America, proved to be difficult to obtain in this country after the war, and were often large and cumbersome; they also required skilled handling. The introduction of syringe services has led to increasing numbers of hot-air ovens being used for sterilization, and it was primarily because of the formation of a syringe service in this area that the present investigations were undertaken.

\section{Aim of the Investigation}

Our preliminary investigations were made to assess :

(1) Whether the heat actually penetrated to the syringes. (2) Whether the type of packing employed was satisfactory. (3) At what position in the oven should the thermocouple of an automatic recording apparatus be placed.

Normally it has been the practice to test an oven with thermocouples placed in glass tubes while the oven is empty. The efficiency of the oven is gauged by the degree of correlation of the temperature levels recorded throughout the oven. In our investigations the ovens were tested fully loaded just as in a syringe service, since it is only when heat penetrates the centre of the syringes that sterilization is effective. In the literature opinion varies considerably as to what the temperature of the oven should be and the time required to ensure adequate sterilization. Temperatures varying from approximately $140^{\circ} \mathrm{C}$. to $180^{\circ} \mathrm{C}$. from half an hour to two hours are mentioned. However, it is probable that in this country $160^{\circ} \mathrm{C}$. for one hour, as advocated by the Medical Research Council Memorandum No. 15 (1945) on the sterilization of syringes, would be accepted in a court of law. This memorandum further recommends that ovens should be loaded cold and allowed to heat up to $160^{\circ} \mathrm{C}$. and held at this temperature for one hour. In our investigation this temperature has been used in all the tests undertaken.

\section{Recommendations in the Literature}

Although experience with hot-air sterilization dates back as far as 1881 , Koch and Wolfhügel (1881) found that dry heat was not as effective as wet heat in destroying bacteria and spores, and that, although vegetative bacteria could be destroyed at a temperature of just over $100^{\circ} \mathrm{C}$. for one and a half hours, spores required a temperature of $140^{\circ} \mathrm{C}$. for three hours. The type of hot-air oven is, however, not mentioned, and it is probable that these were of the gas type.

Since then a number of sterilizing temperature levels have been advocated, and, in view of the

TABLE I

TEMPERATURE LEVELS FOR HOT-AIR OVENS

\begin{tabular}{|c|c|}
\hline Name & Hot-air Sterilizer \\
\hline 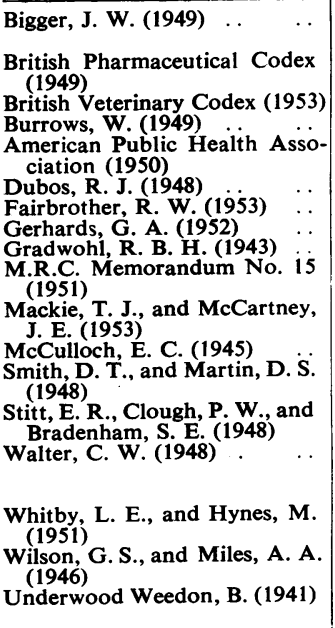 & 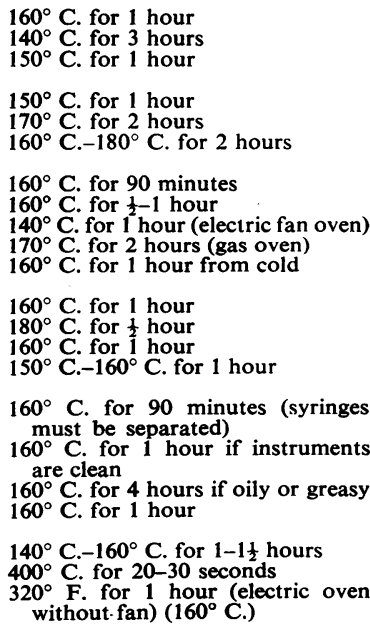 \\
\hline
\end{tabular}


variety of recommendations, have been set out in Table I. In the majority the type of oven has not been specified, but Gradwohl (1948) quotes $170^{\circ} \mathrm{C}$. for two hours in a gas oven as being satisfactory. Weedon Underwood (1941) advocates $160^{\circ} \mathrm{C}$. for one hour, and illustrates a satisfactory electric oven without a fan. More recently, however, Gerhards (1952) using a fan oven has shown that spores can be satisfactorily destroyed at $140^{\circ} \mathrm{C}$. for one hour. Ewald and Schmid (1953) also draw attention to the importance of testing electric ovens with maximum thermometers, and found large variations from shelf to shelf. Walter (1948) in his monograph The Aseptic Treatment of Wounds draws attention to the limitation of the hot-air oven, and points out that most ovens heat up slowly and unevenly and that sterilization is therefore uncertain. He advocates that the whole load should reach $160^{\circ} \mathrm{C}$. and be held at this temperature for one hour, provided that the instruments are clean and free from oil or grease. If the instruments are oily or greasy he considers four hours after $160^{\circ} \mathrm{C}$. satisfactory, but also advocates that "air blowers" in the ovens hasten heating and assure uniform conditions.

\section{Method of Investigation}

In our investigations "chance" all-glass metaltipped syringes were used, and were packed in either thick-walled glass tubes or metal containers. It can be stated now that it was found by experiment that the type of containers used made no appreciable difference to heat penetration or the temperature reached. In the preliminary experiments needles were also used, and these were packed in glass test-tubes with cot on-wool plugs. Throughout the experiments attempts were made to simulate the exact conditions of a normal syringe service. Normally syringes were loaded into wire baskets 9 in. $\times 9$ in. $\times 9$ in. of a type commonly used in bacteriological practice. The baskets were either (1) loosely packed, when syringes in their containers were held apart by metal skewers, leaving a gap of approximately $\frac{1}{2}$ in. through which air could flow freely, or (2) tightly packed, when as many syringes in their containers as possible were packed in the baskets.

The number of baskets loaded into each oven depended upon the overall capacity. In each case the load was considered as average for the size of the oven. No attempt was made to overload the oven. In two ovens metal trays were provided which did not allow the use of baskets. In these ovens the svringes were laid two deep on their sides to allow the free passage of hot air as indicated in Fig. 1. In selecting ovens care was taken to choose those which were, or might be, in normal use in the laboratory, and were of the standard pattern produced by wellknown laboratory furnishers. A multipoint copper

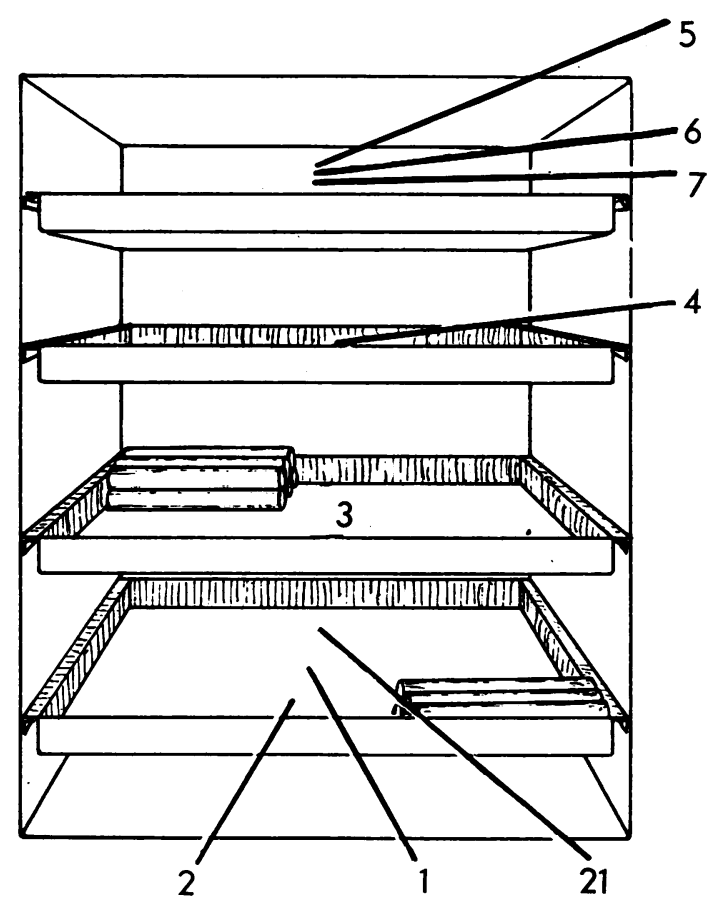

FIG. 1.-The distribution of syringes in electric oven B, packed loosely, 40 syringes to a shelf. The figures indicate the position and number of the thermocouple used.

constant thermocouple temperature indicator was used throughout the experiments. The indication was obtained by a null point method using a potentiometer circuit of high precision, i.e., back E.M.F. was applied against the E.M.F. generated by the thermocouple until a sensitive galvanometer registered zero, and the readings of the potentiometer were calibrated against actual temperatures applied to the thermocouples, which were measured with sensitive thermometers immersed in hot oil. This method cancels out any internal electrical errors in the system.

Specially calibrated mercury and glass thermometers graduated from $100^{\circ}$ to $200^{\circ} \mathrm{C}$. in half degrees were placed in position as indicated by the manufacturers. The readings from these thermometers were considered to indicate the air temperature of the oven, since it is these readings which guide the operator and are used as a reference point in all experiments except in one electric oven in which the manufacturers had provided a circular-dial type of thermometer.

Special borings were made in the glass piston of some syringes and thermocouples and leads passed into the cavity so that the point rested as close to the base as possible. The syringe was then placed in a container and the lead so arranged that normal packing was not disturbed. The wire leads were introduced into the oven through the hole used for the thermometer. Normally 10 or more leads were used in each experiment, and were distributed in 
baskets throughout the oven. Usually two tightly packed baskets and two loosely packed baskets were placed on the top and bottom shelves respectively, and leads placed in the centre of each. Other leads were also placed in a syringe on the outside, or in other baskets. The type of distribution of the baskets and position of thermocouples are shown in Fig. 2. This distribution was varied slighily from oven to oven according to its capacity and the experience gained in previous experiments.

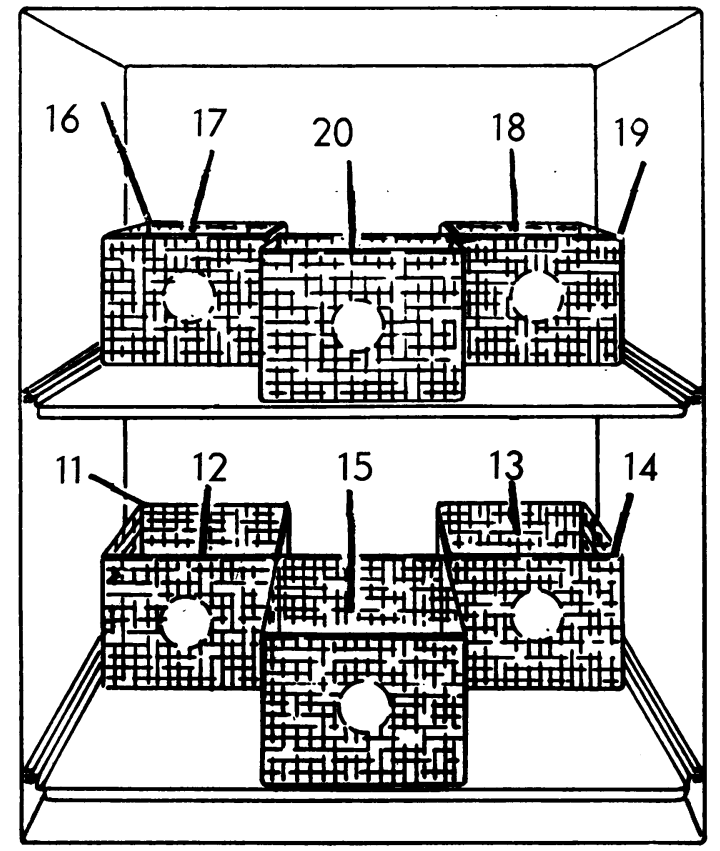

FIG. 2.-The distribution of the thermocouples and baskets used in most of the experiments. The number indicates the number of thermocouple used. Thermocouple: 11 and 16, outside loosely packed syringes. 12 and 17 , centre loosely packed syringes. 14 and 19 , outside tightly packed syringes. 13 and 18 , centre of tightly packed syringes. 15 and 20 , centre of loosely packed metal syringes.

In this manner we have tested two gas ovens and four electric ovens without fans and two with fans. With the exception of one gas and one electric oven, all ovens tested conformed to the $\pm 3^{\circ} \mathrm{C}$. when tested empty. In the experiments the ovens were loaded cold and allowed to heat to $160^{\circ} \mathrm{C}$. and held for one hour at that temperature during which time the temperature recordings were taken at 10 to 20 -minute intervals.

\section{Results}

Gas Ovens. - In the two gas ovens wide variations of temperature were apparent from the start and generaliy the temperatures were considerably lower in the bottom shelf than in the top. It was also found that syringes tested near to the back wall were consistently overheated. In the first oven (gas oven A) the reference thermometer reached $160^{\circ} \mathrm{C}$. after 50 minutes. At that time the majority of the syringes had not reached $130^{\circ} \mathrm{C}$., and differences of approximately $60^{\circ} \mathrm{C}$. were noted, if tightly packed syringes are excluded (leads 6 and 9). Most of the syringes on the top shelf seriously overshot the air temperature of the oven, whereas at the end of one hour most of the syringes on the lower shelf, except those placed at the back, had not reached $160^{\circ} \mathrm{C}$. Even after one hour there was a variation of $40^{\circ} \mathrm{C}$. The recordings of thermocouples are shown in Fig. 3. Similar findings were found in the second gas oven (gas oven B), which also showed some interesting features. This oven had been claimed by its owner as being satisfactory because of the time taken for it to reach $160^{\circ} \mathrm{C}$. It was thought that this slow rise would ensure an even distribution of heat. Experiments showed that this oven took 136 minutes to reach $160^{\circ} \mathrm{C}$. At this time six out of the 10 thermocouples were below $155^{\circ} \mathrm{C}$, the lowest recording being $146^{\circ} \mathrm{C}$. The remaining four were at temperatures varying from $166^{\circ} \mathrm{C}$. to $182^{\circ} \mathrm{C}$. However, during the next 15 minutes the oven air temperature had risen to $163^{\circ} \mathrm{C}$. and the syringe temperature varied from $152^{\circ} \mathrm{C}$. to $192^{\circ} \mathrm{C}$. At the end of one hour six of the syringes were between $193^{\circ} \mathrm{C}$. and $169^{\circ} \mathrm{C}$., while one syringe still had not reached $160^{\circ} \mathrm{C}$., giving an overall variation of $34^{\circ} \mathrm{C}$.

Electric Ovens.-The four electric ovens all showed improved performance over the gas ovens. In one electric oven there was only $9^{\circ} \mathrm{C}$. difference in the recorded temperature of the syringes at the end of one sterilizing period. In the other three the overall variations of the temperature at the conclusion of the sterilizing period were $21^{\circ} \mathrm{C}$., $28^{\circ} \mathrm{C}$., and $17^{\circ} \mathrm{C}$. if the tightly packed syringes are excluded. This in itself might prevent certain syringes from reaching a temperature necessary to ensure bacterial death. Perhaps the greatest disadvantage of the electric oven without fan is the time taken for the syringes to take up heat. Even with electric oven $\mathrm{C}$, in which the final overall variation was less than $9^{\circ} \mathrm{C}$., heat was slowly taken up. For example, although the temperature of the oven reached $160^{\circ} \mathrm{C}$. in 63 minutes (and no tight packing was used), the syringes at this time varied from $122^{\circ} \mathrm{C}$. to $150^{\circ} \mathrm{C}$. $\left(32^{\circ} \mathrm{C}\right.$. $)$, and even after 15 minutes there was a variation of $25^{\circ} \mathrm{C}$., the temperature of one syringe being only $126^{\circ}$ C. It was not until three-quarters of the sterilization time had been completed that the temperature of the syringes became stabilized. These recordings are shown on Fig 4. This oven 
FiG. 3.-Serial temperature recordings of syringes in gas oven A started from cold. Syringes Nos. 1 and 8 were placed in the back of the oven on the bottom and top shelf respectively. $O$ denotes those syringes placed on the bottom shelf. $X$ denotes those placed in the centre of tightly packed baskets. Note the wide variation of temperature and the length of time taken for syringes to attain the temperature of the oven.
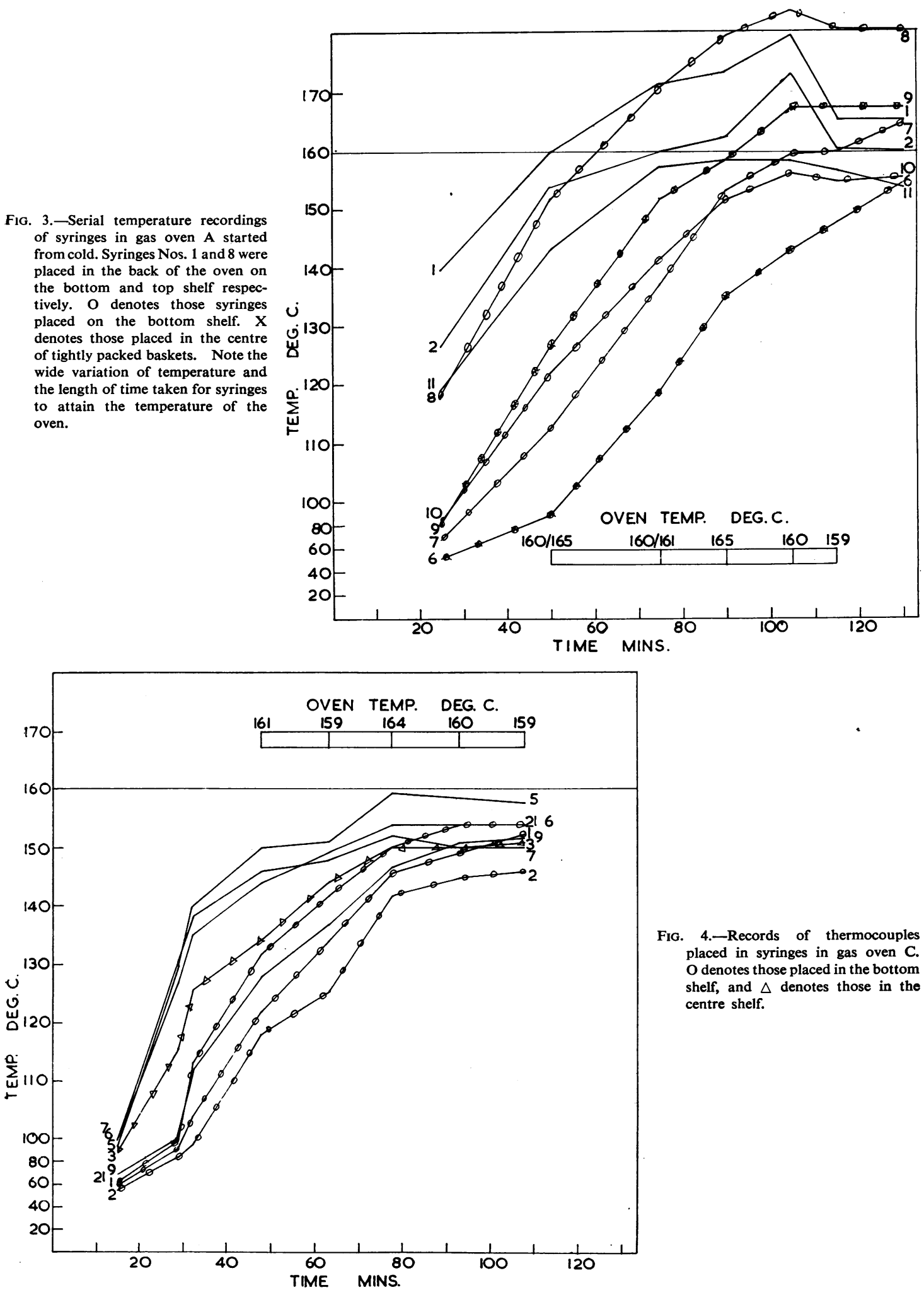

FIG. 4.-Records of thermocouples placed in syringes in gas oven C. $O$ denotes those placed in the bottom shelf, and $\Delta$ denotes those in the centre shelf. 
Fig. 5.-Thermocouple reading from electric oven $D$. Note the slow rise of temperature and the wide distribution of temperature at the end of one hour's sterilization.
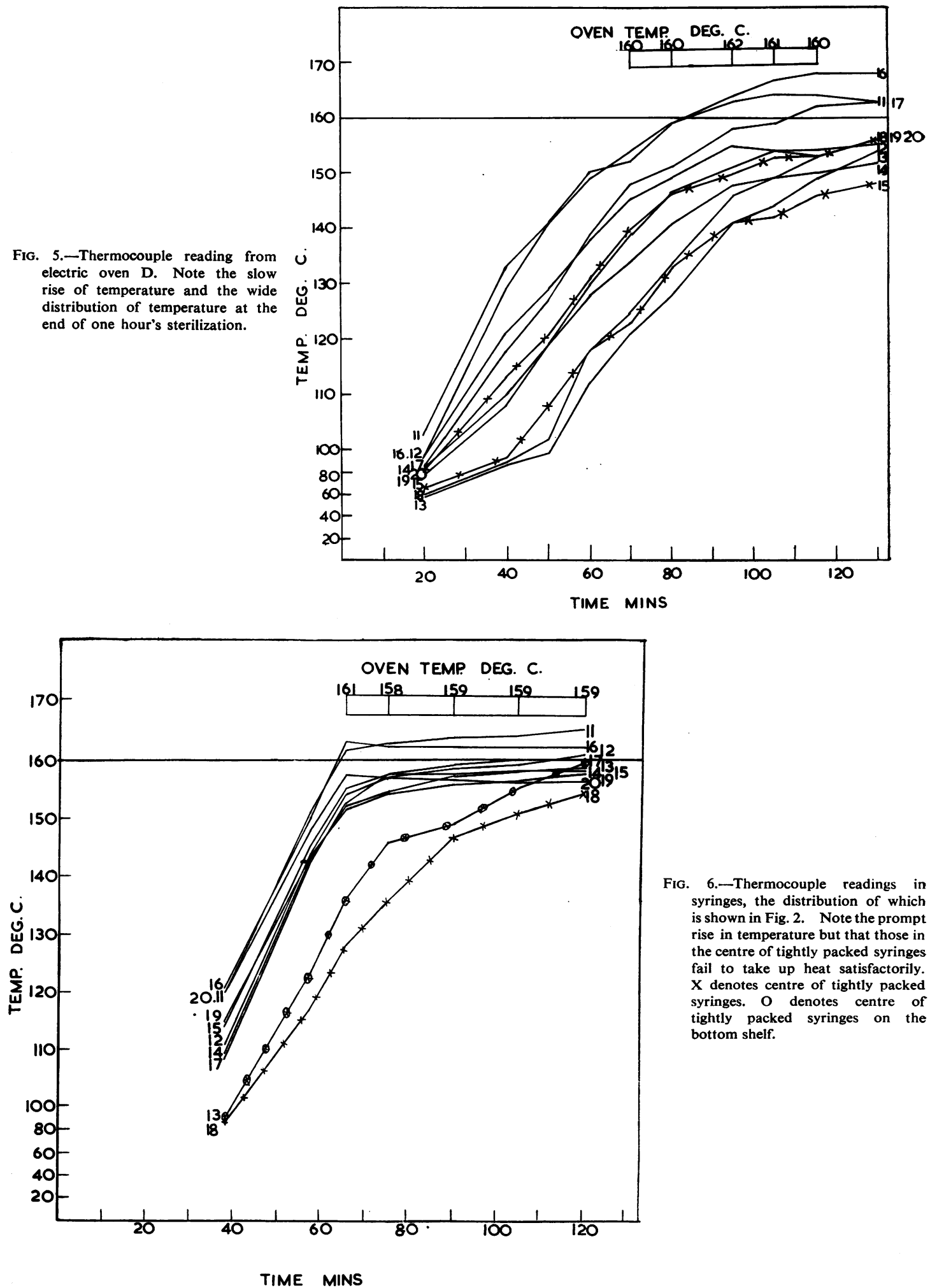

Fig. 6.-Thermocouple readings in syringes, the distribution of which is shown in Fig. 2. Note the prompt rise in temperature but that those in the centre of tightly packed syringes fail to take up heat satisfactorily. $\mathbf{X}$ denotes centre of tightly packed syringes. $O$ denotes centre of tightly packed syringes on the bottom shelf. 
was fitted with four shelves and a built-in circulardial type thermometer. It is probable that the dial in this case was faulty and by its correction the temperature of the syringes could have been maintained in the neighbourhood of $160^{\circ} \mathrm{C}$. It would not, however, have altered the length of time necessary to bring the syringes up to a stabilizing temperature. It also points out the necessity of checking the recording temperature with that attained by the syringes. Fig. 5 shows the recording in electric oven $D$, which again shows the delay in the time taken for the syringes to take up heat, and suggests that there is a danger that some of the syringes may not receive sufficient heat to ensure sterilization. Electric ovens $A$ and $B$ showed exactly similar trends.

Fan Ovens.-Two different patterns of electric oven with fans were tested, and it was interesting to note that, although the final overall variation of temperature in the syringes was less than $8^{\circ} \mathrm{C}$. and $10^{\circ} \mathrm{C}$., the tightly packed syringes again showed a serious delay in taking up heat. In these ovens heat was promptly taken up as shown in electric oven B with fan (Fig. 6), and the overall variation of syringe temperature was less than $12^{\circ} \mathrm{C}$. and $13^{\circ} \mathrm{C}$. from the start of the sterilizing period, the lowest temperature of any syringe recorded, excluding tightly packed syringes, being $144^{\circ} \mathrm{C}$. This ensures that all syringes have similar heat treatment.

Overloaded Ovens.-In all experiments so far quoted, there was a delay in the time taken for the packed syringes to take up the oven temperature. It was therefore decided to test specifically the effect of tightly packed syringes and at the same time using syringes of varying sizes. For this experiment electric oven A, with fan, was used, since it appeared to be the most efficient oven (Fig. 7) tested at that time. The recorded temperatures of thermocouples are shown in Fig. 8 and should be compared with Figs. 3, 7, and 9. It is seen that the syringes in the centre of the tightly packed baskets take a considerable time to reach the required temperature, and further that the overloading of the oven interferes with the normal air flow with the result that many of the syringes fail to reach oven temperature. In general the bottom shelf shows a lower temperature, confirming the interference with air flow which is normally higher in ovens with fans.

Heat-loaded Ovens.-The Medical Research Council Memorandum No. 15 (1945) specifically makes the point that ovens should be loaded cold and the oven allowed to attain the temperature of $160^{\circ} \mathrm{C}$., when it should then be held at this temperature for one hour. However, in a busy syringe service considerable time may be wasted to allow the oven to cool to room temperature between batches. It was therefore decided to test specifically the effect of loading the oven when still hot. For this purpose the ovens were allowed to heat to $160^{\circ} \mathrm{C}$., and as soon as that temperature was reached the ovens were opened and while they were still hot were loaded with syringes already placed in baskets. The ovens were then allowed to regain the temperature of $160^{\circ} \mathrm{C}$. and held for one hour. Two ovens were tested in this way, gas oven $\mathbf{A}$ and electric oven $\mathbf{A}$ with fan. The distribution of syringes and thermocouples was exactly similar. The temperature recordings are shown in Figs. 8 and 9 and should be compared with Figs. 3 and 6 . No appreciable difference is seen in gas oven $\mathbf{A}$, while in electric oven $\mathbf{A}$ with fan the uptake of heat is more even and complete, presumably because heat has already been absorbed into the fabric of the oven.

\section{Discussion}

It must be clearly understood that the placing of thermocouples enclosed in syringes and shielded by containers are all variables which contribute to the variations in temperature shown earlier. The arrangement of the basket also plays an important part in interfering with hot air currents. The experiments must therefore be considered as indicating trends of temperature changes rather than definitive alterations. Nevertheless, in constructing any piece of sterilizing apparatus it is essential to ensure that all articles receive similar heat treatment, and that the temperature reached corresponds to that of the recording thermometer, reaching this temperature with a minimum of delay. With the exception of fan ovens the majority of ovens do not meet these criteria. In addition, our experiments again stress the importance of avoiding tight packing, since it is clear that by tight packing it is possible that some syringes may receive insufficient heat treatment and may not reach the thermal death point of bacteria. There must be a free flow of air around all articles to be sterilized, and enclosing syringes in metal boxes or similar sealed containers may prevent the heat penetrating to those syringes near the centre. It is also clear that overloading ovens may seriously interfere with heat distribution, a point which has been frequently stressed in the American literature but which does not seem to have had sufficient emphasis in Britain. Maxwell Savage (1936) has also shown that tight packing 
Fro. 7.-Reading of electric oven A with fan. $X$ denotes those placed in syringes in the centre of tightly packed syringes. $O$ denotes those placed in lower shelf. In the final stages the oven was allowed to overheat, and the rapid take-up of heat should be noted.
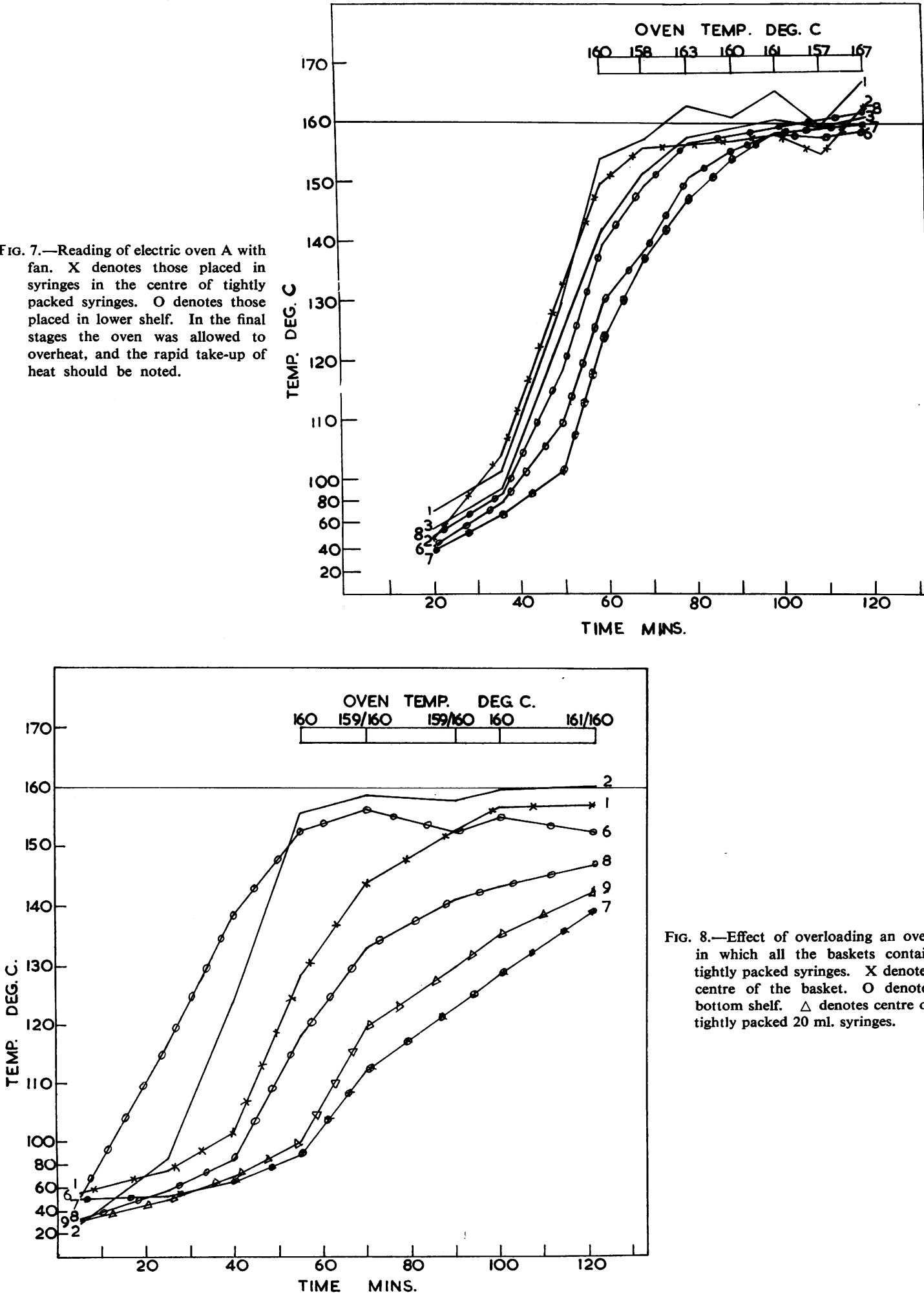

Fig. 8.-Effect of overloading an oven in which all the baskets contain tightly packed syringes. $\mathbf{X}$ denotes centre of the basket. $O$ denotes bottom shelf. $\Delta$ denotes centre of tightly packed $20 \mathrm{ml}$. syringes. 
Fig. 9.-This should be compared with Fig. 3 (gas oven A). The same oven position of syringes and baskets, number of thermocouples, and symbols as those used in Fig. 1, the only difference being that the oven was first heated to $160^{\circ} \mathrm{C}$. and temperature of $160^{\circ} \mathrm{C}$. before the sterilization procedure was restarted. Note the time saved by this method, and that the uptake of heat and variation of temperatures recorded are similar to that loaded cold. loaded hot and allowed to regain the
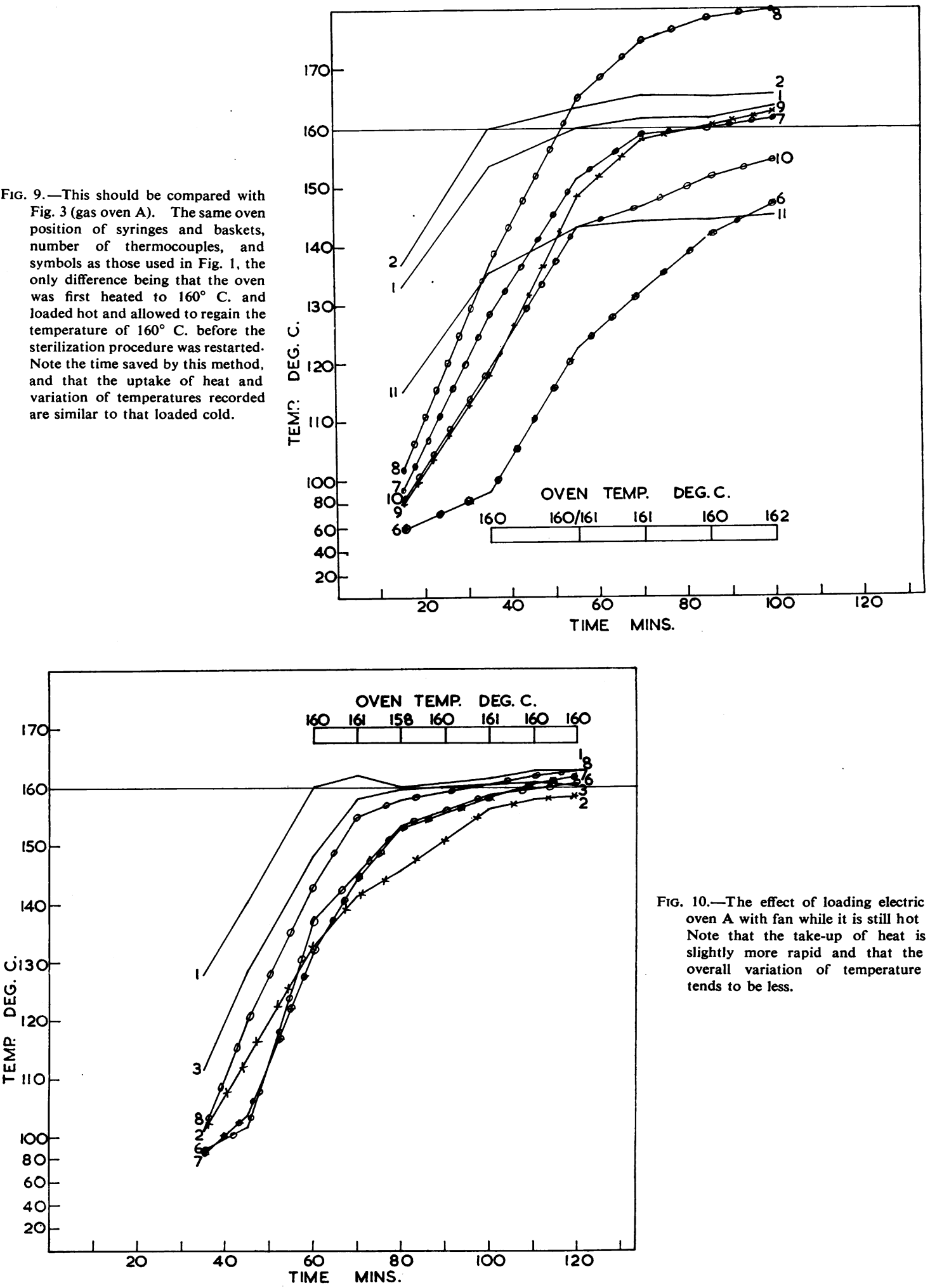

FIG. 10.-The effect of loading electric oven A with fan while it is still hot Note that the take-up of heat is slightly more rapid and that the overall variation of temperature tends to be less. 
is equally dangerous in autoclaves and it is essential that steam should penetrate to all articles to be sterilized.

The uneven distribution of temperatures recorded in gas ovens suggests that this type of oven is unsuitable and unreliable for syringe services. Not only is there a danger that heat may not penetrate, but also there is a possibility that excess of heat may cause the solder to disintegrate if glass and metal syringes are used. A further danger, shown by Gerhards (1952), is that the point of the needle may be seriously damaged by extremes of temperature.

In the electric oven without fan the overall variation of temperature was not so great as with a gas oven. However, without fans the transfer of heat is slow, and variations even after stabilization may be extreme and suggest that the heat treatment may be of such short duration and of such low temperature that the thermal death point of bacteria may never be reached. It is therefore important that in the electric oven the time of sterilization must be so adjusted that the instrument showing the lowest temperature receives adequate heat treatment. This may mean that some articles receive more heat and for a longer period than is necessary. In a busy syringe service when ovens are in constant use the time may be of importance. The value of the fan oven is that the load takes up the heat rapidly and equally from the time the oven reaches the desired temperature and that the variation of temperature from one syringe to another is less than $10^{\circ} \mathrm{C}$. This indicates that in a fan oven the temperature need not be so high nor the heat treatment so prolonged, both valuable assets in a busy syringe service.

The belief that a slow rise in temperature is necessary to ensure that heat is taken up evenly is discounted by experiences in gas oven B, for in . this experiment 136 minutes elapsed before the oven reached $160^{\circ} \mathrm{C}$., and even then a wide variation of temperature was recorded. The experiments of loading the oven while hot indicate that the heat is taken up more evenly and more quickly. This is probably due to the fact that the fabric of the oven has already absorbed heat and allows a greater and more even transfer to the articles to be sterilized. The fact that so many of the ovens showed a satisfactory distribution of heat when empty suggests that perhaps more rigorous tests should be employed by the manufacturers before issuing ovens for distribution. It is suggested that probably a standard load when testing might be necessary to ensure an adequate margin of safety.
No attempt has been made in this investigation to determine the thermal death point of bacteria usually encountered. Experiments with spores with the oven at $160^{\circ} \mathrm{C}$. for one hour seemed satisfactory. However, no record of temperatures after loading seems to have been carried out, and it is probable, in accordance with Gerhards' paper (1952) on the thermal death point of bacteria in fan ovens which stated that $140^{\circ} \mathrm{C}$. for one hour was sufficient, that this temperature is in fact effective, and it is assumed that the reason why so many authoritative manuals have specified a higher temperature is because in the past the wide variation of temperature within gas and electric ovens necessitated this precaution.

The organization of syringe services demands simplified cleansing and sterilizing procedures. The fact that in autoclaves syringes should be sterilized unassembled to ensure adequate steam penetration makes this method clumsy, since it requires two further steps. The syringes must be reassembled after sterilization and the entrance holes to the containers closed. Hot-air sterilization is therefore preferable, since it avoids both these extra operations. Preliminary experiments with thermocouples with syringes during the process of boiling show that even after three minutes the syringe is not yet at the temperature of $100^{\circ} \mathrm{C}$. and that by wrapping in lint heat penetration is prevented for five minutes or longer, and proves that little reliance can be placed on this method of sterilization. The work of Bigger, Blacklock, and Parrish (1940) proves conclusively that even after 20 minutes not all bacteria may be destroyed, and this is accentuated if any biological material adheres to the syringe. Removing adherent biological fluids such as pus or blood together with possible spores is one of the most important preliminary steps in the sterilizing process. Once this has been done, a standard period of dry heat treatment will ensure adequate sterilization.

Spores are known to be most resistant of all organisms to dry heat. They therefore suggest themselves as suitable test organisms, but they too vary in their resistance to heat. Unfortunately most authors do not indicate the precise organisms used to test the reliability of their ovens, and it is possible that this omission accounts for some of the discrepancies in the literature. For this reason it is essential to carry out further work on the thermal death-point of organisms in the presence of biological fluids with special reference to the length of time and the temperature necessary to ensure sterilization. An authoritative body should define the organisms to be used for testing dry heat ovens. 


\section{Summary}

An investigation with multipoint thermocouples into loaded ovens has been carried out. Two gas ovens showed a wide variation of temperature, which makes these instruments unsatisfactory for syringe services. Experiments with four electric ovens without fans showed that in the main heat is taken up slowly and that, even though close correlation of temperature is obtained when the oven is empty, wide variations of temperature may occur. In the fan oven heat is promptly absorbed and the variation of temperature is reduced. Loading ovens while still hot does not interfere with the transfer of heat to the articles to be treated, and in fact in the majority of instances it is to be preferred, but tight packing of syringes and needles is condemned as unreliable.

Our thanks are due to the directors of Messrs. Townson \& Mercer for the loan of apparatus, to Mr. W. H. R. Saunders for assistance in the technical work, and to Mrs. W. Tuke, S.R.N., for general assistance.

\section{REFERENCES}

American Public Health Asscciation (1950). Diagnostic Procedures and Reagents, 3rd ed. New York.

Bigger, J. W. (1949). Handbook of Bactericlogy, 6th ed. Ballière, Tindall and Cox, London.

- Blacklock, J. W. S., and Parish, H. J. (1940). Brit. med. J., 1, 582.

British Pharmaceutical Codex (1949). Pharmaceutical Press, London

British Veterinary Codex (1953). Pharmaceutical Press, London.

Burrows, W. (1949). Jordan-Burrows Textbook of Bacteriology, 15th ed. Saunders, Philadelphia.

Dubos, R. J. (1948). Bacterial and Mycotic Infections of Man. Lippincott, Philadelphia.

Ewald, H., and Schmid, W. (1953). Öff. GesundhDienst., 15, 159.

Fairbrother, R. W. (1953). A Text-Book of Bacteriology, 7th ed. Heinemann, London.

Gerhards, G. A. (1952). Arch. Hvg., Berl., 136, 547

Gradwohl, R. B. H. (1948). Clinical Laboratory Methods and Diagnosis, 4th ed. Mosby, St. Louis.

Koch, R., and Wolffhügel, G. (1881). Mitt. GesundhAmte. 1, 301.

Mackie, T. J., and McCartney, J. E. (1953). Handbook of Practical Bacteriology, 9th ed. Iivingstone, Edinburgh.

McCulloch, E. C. (1945). Disinfection and Sterilization, 2nd ed. Lea and Febiger, Philadelphia.

Medical Research Council (1945). War Memorandum No. 15. H.M. S.ationery Office, London.

Savage, R. Maxwell (1936). Quart. J. Pharm., 9, 366.

Smith, D. T., and Martin, D. S. (1948). Zinsser's Text Book o Bacteriology, 9th ed. Appleton Century Crofts, New York.

Stitt, E. R., Clough, P. W., and Branham, S. E. (1948). Practical Bacteriology, Hematology, and Parasitology, 10th ed. Blakiston, Philadelphia.

Underwood, W. B. (1941). Text Book of Sterilisation, 2nd ed. American Sterilizer Co., Erie, $\mathrm{Pa}$.

Walter, C. W. (1948). The Aseptic Treatment of Wounds. Macmillan, London.

Whitby, L.. and Hynes, M. (1951). Medical Bacteriology, 5th ed. Churchill, London.

Wilson, G. S., and Miles, A. A. (1946). Topley and Wilson's Principles of Bacteriology and Immunity, 3rd sd. Arnold, London. 